\title{
The Heroic Identity and the Concept of Heroism in Henry Wadsworth Longfellow's Hiawatha (1855)
}

\author{
Ismael M. Fahmi . Lanja A. Dabbagh \\ English Department, College of Languages, Salahaddin University
}

\begin{abstract}
This research selects portions from H. W. Longfellow's epic poem Hiawatha to make out the real identity of the hero, and the actual features of heroism in this work, which is about the Native Americans. Usually, the hero is an individual, but very different and very exceptional. This research explores that point in particular. The hero has some weak points which may call into question his identity as a hero and may even encourage a re-definition of Heroism as a concept. Some of the themes to address in the paper are the following:

1. The birth of the hero. Is he a divine being sent from the sky, or is he a foundling, a parentless creature?

2. The hero's interest in war- waging as his own reason d'etre.

3. The hero's interest in beautiful women.

The paper point out the constituents of the sublime elements in this epic, focusing on the distinctive expressions; the effective expressions; the effective epithets; the powerful or persuasive impact to entrance the recipients of the epic entitled Hiawatha.
\end{abstract}

Key Words: Epic, Longfellow, Heroism, Hiawatha.

\section{Introduction}

The Song Hiawatha (1855) is a narrative poem by Longfellow in unrhymed trochaic tetrameter. Its novel and facial meter has led to many parodies and imitations. The meter derives from Finish Epic Kalevala, which this poem resembles in spirit as well as in several striking passages.

Hiawatha is reared by his grandmother Nokomis, daughter of the Moon, among the Ojibway on the southern Shore of Lake Superior. He learns the language of the birds, the animals, and the fish. He secures magic mittens that will crush rocks and magic moccasins that enable him to take mile- long strides, and he seeks vengeance on his father, Mndjekeewis, the West Wind, for a wrong committed against his mother, Wenoma, the fight ends in reconciliation. Hiawatha returns as the defender and civilizer of his people. Later, he defeats Mondamin, the corn spirit, from which he builds a birch bark canoe, has a contest with Nahma, the sturgeon, who swallows both the canoe and warrior, and destroys pearl- feather, sender of disease and death. Hiawatha, then, marries Minrehaha, lovely daughter of an arrow-maker of once hostile Dakotah. The wedding feast and song of the evening star inaugurate an idyllic time of peace and culture, over which Hiawatha rules till the death of his friends, Chibiabos the musician and Kwasind strong man. 
PauPuk- keewis insults Hiawatha, who kills him. In consequence, famine and fever visit the people and claim Minrehaha golden swarms of bees appear as forerunners of the whites, whose coming, Hiawatha prophesied. He tells his people to heed a missionary offering a new religion. He then departs for the Isles of the Blessed in Keewaydin to rule the kingdom of the West Wind. These "Isles" are a reference to the "Hereafter", or the "Aftermath", or "the other world". Hiawatha wants to give the impression that he is an immortal, undying individual. There is a little in $19^{\text {th }}$ century poetry in USA to parallel The Song of Hiawatha. In the use of language, the poem uses exact words rather than decoration words. Even though Longfellow is a poet rather than a painter, he can depict the character of the hero clearly. The hero is presented as an unblurred, a clear, and a definite image. In the poetic anaemea of his days, he turned to genuine American themes, which made him a major poet. He paid attention to a vital period in the life of his country. He portrayed HERO AS AN ADEAL person but in a critical light, rather than critical judgement.

The above has been based on an overall reading of the poem as a whole.

\section{The Importance of the Poem}

According to Lynn Altenbernd and Leslie Lewis, the use of myths, legends, and archetypes in poetry found a powerful expression in Shelley's "Prometheus Unbound" (1820). "Similarly, the idea is that New Worlds is a land where man, at last exempted from the tragic history of all other nations, will realize their dreams of freedom in innocence and peace maybe called the American Myth" (Lewis, P. 80).

The Song of Hiawatha, in the true American spirit, celebrates the legend of a great man. $\mathrm{He}$ is more than a great man. He is an icon. Relevant to the kind of personality represented by Hiawatha, here is Fuad Shaban's definition of legend: “A story of a national or religious figure which has a basis in fact but which has been expanded by the imagination of the successive writers" (Shaban, P. 58).

As to why Longfellow preferred to call his poem Song, W. H. Peters has something interesting to say, which will be quoted below in a rather lengthy fashion:

What Homer's poem and Beowulf have in common (as opposed to the Aneid and Paradise Lost) is that they are products of an "heroic age" (i. e., an age when virtue is largely identified as strength, and poets sign of this virtue). Because the poets in heroic societies sang a memorized poem, their lines abound in stock epithets (e.g. Homer's 'rosy- figured dawn') and repeated lines. Such repetitions ... are called formulas; they not only afforded, pleasure to the hearers by their familiarity but also helped the poet compose and keep his material in mind. An obvious imitation of this formulatic poetry is Longfellow's The Song of Hiawatha.

(Peters, P. 37)

Here, it can be seen that Longfellow combined Native Americans, Finish, Anglo- Saxon, and ancient Homeric practices altogether in the composition of his long legendary song. Peters himself goes on, in his explanations on p. 57 of the same handbook, to define the poetic narrative based on a myth as "large, controlling image that gives philosophic meaning to the facts of ordinary life ... All real life convictions involve a mythology ... Wars may be described as the clash of mythologies" (Peters, P. 57). 
Peters admits that his viewpoint above derives from Mark Schorer's study of William Blake's myth- making. So, in addition to Altenbernd and Leslie's viewpoint that Shelley's "Prometheus Unbound" propelled the use of mythical, legendary, archetypal figures in poetry since the $19^{\text {th }}$ century, there is Schorer's and Peter's viewpoint that it was Blake who was the pioneer their way. We propose that it was H. W. Longfellow who was more original than both Blake and Shelly. He seems to have worked on a raw material seldom attempted before, which is the Native American Traditions of oral heroic songs. In this sense, Longfellow is closer to Homer and Beowulf poet than to the British poets Blake and Shelley. Shelley reworked the Greek myths and legends. Blake, also, did this but created his own poetic world ex nihilo. Longfellow did to the Native American oral Traditions what the original bards of the past did.

One of the initial impressions which the readers of this work get is the identification of the genre as a "song by the composer of the poem. Longfellow is making it clear that the Native American literary culture is oral. It is "Orature" rather than "literature".

The song recited, sung, chanted, or performed by the sweet Native American voices and accents is deeply touching. The combination of the lyric, the narrative, and mythical elements expresses the joys, the sufferings, the high hopes, and the disappointments of the native tribes. As Alan Warner writes in his Preface to English Poems and Ballads: An Anthropology of Narrative Verse: "In communities where there is no reading or writing or where only a few people can read or write, poetry goes hand- in- hand with dancing or singing, specially singing" (P. V). Hence, Longfellow made the right choice of the nomenclature, calling the poem a "song".

The rest of this paper will focus on a close reading of the selected lines.

\section{Hiawatha's Identity}

The Song of Hiawatha, being a narrative about a great tribal chief provides much- needed information regarding Hiawatha. He is portrayed as the greatest chief, statesman, spiritual leader, and medicine man of the sixteenth century. He organized the Iroquois tribes of the North American Indigenous Natives. This song is focused on:

a. The personality,

b. The deeds, and

c. The role which this great man played in the destiny of his own people.

To be sure, he achieved for his own name an undeniable kind of immortality. He was the last truly great chief. However, his personality which accomplished everlasting fame for itself, left the Indigenous Natives. In a defenseless position. Hiawatha surrounded his own existence with mysteries and supernatural events, claiming that rivers, winds, flames, and clay obeyed him. He was the moving force behind the forests, the beasts, the birds, and fish. Even though Hiawatha's origins are largely obscure, he managed to emerge as the undisputed Chief of the Iroquois.

Who was he? The text of the poem is intentionally ambiguous, for the Native American audience of the nineteenth century. But seen from a critical angle, it can be speculated with much certainty that Hiawatha was a foundling left behind in the forest to meet his own fate. He might have been from a different race than the Iroquois. Perhaps, he was the fruit of unwanted pregnancy of a white biological parent with a partner from the Indigenous natives.

Thus, the poem sings joyously that Hiawatha is the son of WENONAR, the grand- daughter of the moon goddess, and MudjeKeewis, the god of the west wind. Hiawatha was raised by 
Nokomis, the daughter of the moon goddess. The poem is in twenty- two chapters. Hiawatha is introduced in chapter III.

As Hiawatha is a foundling unable to prove who his parents were, he makes up his divine genealogy as follows:

The moon goddess

$\downarrow$

Nokomis, moon daughter

$\downarrow$

Wenonab, grand- daughter of the moon \& Mujekeewis the god of the west wind $\downarrow$

\section{Hiawatha}

It seems that Hiawatha's complexion different from bronze or red, which is the Native Americans' skin color. He seems to be white. Thus, he tries to justify his whiteness by claiming to be the grand child of the moon, which shines with a bright, whitish, silver, argental tone of color. Thus, there can hardly be anybody among the gullible Indians who doubts this man's claims:

By the shore of Gitchee Gume,

By the shining Big-Sea Water,

Stood the Wigwam of Nokomis,

Daughter of the Moon, Nokomis,

Dark behind it rose the forest,

Rose the black and gloomy pine-trees,

Rose the firs with cones upon them;

Bright before it beat the water,

Beat- the clear and sunny water,

Beat the shining Big-Sea-Water,

There the wrinkled, old Nokomis

Nursed the little Hiawatha [.]

(Chapter III, lines 1-11)

The earlier170 lines suggest that Hiawatha was a foundling abandoned by his parents in the forest. We must presume that he had only the moon to look at for a long time. Thus, he claims to have been looked after by the moon. But, he has to make the moon seem more important than it really is: it is the deity of the moon as an object of worship: the Moon as a Deity. He is the descendant of the gods and goddesses. He is self-taught. Meaning that the moon and the west wind gave him survival lessons:

Many things Nokomis taught him

Of the stars that shine in heaven [.]

(Lines 23- 24)

A statement by George Skiner is much applicable in this context: “... buried pictures or metaphors play a large role" (Skiner, P. 115)/

Hiawatha must have been stayed long time in isolation from all human contacts. He understands the way animals communicate:

Then the little Hiawatha 
Learned of every bird its language,

Learned their names and all their secrets,

Talked with them whenever he met them

Of all beasts he learned the language,

Learned theirnames all their secrets [.]

(Lines

81- 88)

After he bravely killes a red deer, he cooks it and makes a banquet for the elders of the village nearby:

All the village came and feasted

All the guests praised Hiawatha,

Called him strong- heart, soan-getaha!

Called him loon- heart, mahn- go- taysee!

(Lines

$169-$

172)

Delicious Food, in primitive environment is in Steiner's expression, one of the "tongues of men" (Steien, P. 66). Food speaks for Hiawatha to make him eloquently acceptable as the valiant leader of "his" people, even though he comes from obscure origins.

These lines give us the clue that Hiawatha, with his bright mind, was able to link his origins to that village. He needs to avenge himself upon the native villagers by pretending to be their friendly chieftain to pose as their leader, to become their leader, and guide them to their downfall, in order to get even with them. Later on, he will woo and marry the beautiful Minnehaha, the daughter of the famous arrow- maker in the land of the Dacotahs. Thus, Hiawatha lays hands on weapons and controls the destiny of the natives. His advice to the Native Americans before he returns to the moon goddess in the sky is to accept the rule of the white man. After Minnehaha, which means "the laughing waterfall" dies, Hiawatha advises the Native Americans to accept the coming of the white settlers. He, then, follows Minnehaha's spirit to the homeland of the west wind. He has his philosophy as to marriage:

As unto the bow the cord is,

So unto the man is woman,

Though she bends him, she obeys him;

Though she draws him, yet she follows,

Useless each without the other!

Where can such a talented Person take his people? He can make them his worshippers.by making himself look like an extraordinary person, he makes his people vulnerable and a prey to deception. Sadly, this is the situation till nowadays among great people around the world. Even when he dies, he claims to be going to the "Island of the Blessed"

As Steiner says (p.162) "In death, his body rent, the poet sings still ... for the singular power of language to bring and to overcome death".

Thus departed Hiawatha.

Hiawatha the beloved, 
In the glory of the sunset,

In the purple mists of the evening,

To the regions of the home- wind,

Of the Northwest-wind, Keewaydin,

To the Islands of the Blessed,

To the Kingdom of Ponemah, to the land of the Hereafter!

(The Last lines of the poem, p.95, quoted by Geoffrey Moore)

'Beloved', 'Glory', 'Blessed' are the lexical items to emphasize how he ought to be seen and envisioned by his people in a way that embodies personality- cult. As he is an absolute chieftain with divine right to rule his people even after his death, the word which denotes the end of life is carefully avoided. Instead, he simply 'departed', to give the impression that he is still there to rule over the tribes forever. He is now the king of an additional Kingdom called Ponemah in the lands of the Hereafter. His people regard him as an immortal.

\section{Conclusions}

After examining and analyzing parts of Hiawatha, it seems that this work is an example of the function of the supernatural, the unrealistic in life and in existence. Hiawatha is a downto- earth man, who seeks very realistic objectives, but, he follows unrealistic means (like the supernatural, the extraordinary) because he knows that his people are going to believe him.

The research focused on the twisted logic of the narrative that the poet H. G. Longfellow, most probably, wanted to immortalize exactly this weak image of the hyperbole or exaggeration as well as the extra- ordinary contexts, the Native Americans to justify why the white man was eventually able to overcome them and replace them as the predominant population or the most numerous race in North America. This song can tell the readers a lot more in between like the lines about both races and power relation.

\section{References}

1. Altenbernd, Lynn \& Lewis, Lesslie, L. (1967, reprinted 1999) A Handbook for the Study of Poetry. Macmillans.

2. Aitchison, Jean (2012, $4^{\text {th }}$ edition). Words in the Mind. Singapore, Wiley- Blackwell.

3. Bal, Mieke (1977). Narratologies. Paris, Klincksieck

4. Bal, Mieke (1985). Narratology: Introduction to the Theory of Narrative. Translated by Christine Van Boheemen.

5. Barfield, Owen (1994). Poetic Diction . Faber and fabr.

6. Claridge, Jessics (2010) Folk Myths and Legends. McGraw- Hill Far East Publishers, Kuala Lumpur.

7. Hart, James, D. (1986) The Concise Oxford Companion to American Literature, Oxford.

8. Hope, Parker, Katherine (1998). Language and Reality. Oxford University Press.

9. Jones, R. T. (2008) Studying Poetry. Edward Arnold Publishers, London.

10. Moore, Geoffrey (2011) The Penguin Book of American Verse. London.

11. Peters, W. H. (1996) Hand Book for the Study of Literature. United University Press, UK.

12. Shaban, Fuad ((1996) A Short Dictionary of Literary Terms. Dar Al- Fikr Publishers, Damascus University. 
13. Steine, George (1975 first published 1971) Extraterritorial: Papers on Literature and the Language Revolution. Penguin Books.

14. Teun, Van Dijk (1989). Text and Context. London, Longmans

15. Tillyard, E. M. W. (1978 reprinted 1998). Poetry Oblique and Direct. Chatto and Winduns.

16. Warner, Alan (1957 reprinted 1962) English Poems and Ballads: An Anthology of Narrative Verse Chosen by Alan Warner. London, Oxford University Press.

17. Warner, Austin and Weller, Rene (1949) The Theory of Literature. Penguin Books. Third Edition 1968 reprinted 1978. 